\title{
Almudena Grandes. Memoria, compromiso y resistencia Sara Fernández y Helena Talaya (Coords.) Granada, Valparaíso Ediciones, 2017, 256 pp.
}

En mayo de 2017 salió publicado el libro Almudena Grandes: Memoria, compromiso y resistencia, una compilación de artículos de varios autores sobre estudios de la obra de Almudena Grandes.

Este libro empieza con un prólogo de Eduardo Mendicutti, en el que se expresan todo tipo de elogios a la obra de la escritora madrileña, seguido de un capítulo cuyo tema es el origen de Almudena Grandes en su doble dimensión: como persona y en lo concerniente a su desarrollo como escritora. El lector tiene así acceso a más detalles de su vida y trayectoria y a una breve crítica resumida de sus libros.

El capítulo siguiente consiste en una entrevista de las editoras del libro a la escritora. Se destaca allí que Grandes fue educada para vivir en un país que dejó de existir después de la muerte de Franco (p. 35) y que ha escrito sus libros cronológicamente al revés (p. 41). Esto es: desde la contemporaneidad extraliteraria inmediata de sus primeras obras hasta el pasado que trata de recuperar en las más recientes.

Vienen después los capítulos de los distintos especialistas que participan en el volumen. Abre los estudios críticos y académicos Frieda H. Blackwell, quien centra su atención en Los aires difíciles, para analizar el conflicto bélico que dividió hasta el día de hoy a las dos España. La perdurabilidad de las consecuencias del enfrentamiento fratricida guía las pesquisas de la profesora Blackwell, quien se esfuerza en desentrañar "de qué manera se pagan los platos de la Guerra Civil” (p. 43).

Cristina Carrasco estudia Inés y la Alegría, poniendo de relieve en su análisis un hecho de gran interés en la caracterización de los ambientes de la novela y de su personaje principal: la cocina. Aunque pueda resultar paradójico a simple vista, este lugar no es en la obra un espacio de reclusión y aislamiento para Inés, vinculado a roles de género tradicionales, sino todo lo contrario, pues en la novela representa el ámbito en 
donde la protagonista se sentía libre $\mathrm{y}$ en donde sus clientes luchaban contra el régimen de Franco (p. 70).

Malena es un nombre de tango fue el libro elegido por María Castejón para su análisis. De acuerdo con el trabajo de esta especialista, Malena es una "chica de la movida" que busca su identidad inicialmente a través del sexo. Siente que no tuvo éxito en su vida cuando se compara con su hermana gemela, la cual le arrebata todo lo que le pertenecía y anhelaba, incluso a su propio hijo. Esta novela se presenta como un punto de inflexión en la trayectoria creativa de Grandes, pues en la novela la protagonista tiene una conversación con su abuela Soledad en el curso de la cual se conoce que tanto ella como su abuelo fueron republicanos, lo que hace aflorar por vez primera el pasado histórico en las novelas de Almudena Grandes. Al final del libro, Malena parece reencontrarse consigo misma y parece anunciar que es "hora de crear nuevos modelos femeninos" (p. 95).

Ana Corbalán centra su atención crítica en los Episodios de una Guerra Interminable. Hasta el momento en que esta obra ve la luz, Grandes había ofrecido al gran público tres novelas previas en las que afloraba una honda preocupación por que la historia reciente no cayera en el olvido: Inés y la Alegría, El Lector de Julio Verne y Las tres bodas de Manolita. Todas ellas son obras ficticias basadas en acontecimientos históricos reales, en las que surgen intermitentemente figuras que existieron en realidad, como Dolores Ibárruri, La Pasionaria, en Inés y la Alegría. Con los cimientos previos de esta trilogía con claras concomitancias temáticas edifica Grandes, de acuerdo con Corbalán, una "narración detallada" que "ofrece a los lectores un acercamiento ficticio a los personajes, $[\ldots]$ con los que restablece fuertes lazos de simpatía e identificación afectiva" (p. 107).

El primer libro de Almudena Grandes, Las edades de Lulú, fue el elegido por Estrella Díaz Fernández para su colaboración en el volumen. Explica Díaz Fernández que Lulú elige una vida sexual fuera de lo común como forma de transgredir reglas. De ese modo, la novela contiene descripciones tan exactas que le valieron a la autora no solamente el premio La sonrisa vertical, sino también el mérito de que su libro sea uno de los más innovadores en la España de finales de los ochenta.

El conjunto de cuentos que componen Modelos de Mujer fue el objeto de pesquisa de María José Hellín García. En esta obra, 
detalla la estudiosa, las mujeres son presentadas de acuerdo con la tipología descriptiva de los pecados capitales: la envidia, la gula, la ira, la avaricia, la lujuria, la pereza y la soberbia. A pesar de las aparentes diferencias, explica Hellín García que "todas las mujeres intentan ajustar cuentas con la vida" (p. 137). En su trabajo se detiene particularmente en el análisis de "Malena una vida hervida" para explicar que, por su amor a Andrés, la protagonista pasó varios años haciendo un régimen alimentario durísimo que simultaneó con vías de escape, tan originales como extrańas, pues llegó a pagar a personas para verlas comer o bañarse en comida.

El asunto de fondo desarrollado en esta novela es el de los duros imperativos de superficialidad física y apariencia que se exige a las mujeres en la sociedad actual, que se cifra en tallas casi imposibles. Y precisamente la cuestión de la delgadez como modelo regresa con Modelos de Mujer, obra en la que Lola y Eva se enamoran del mismo hombre. Mientras Eva es muy guapa, pero poco inteligente, Lola es "redonda" y eslavista. Cuando, al final, Andrei Rushinikov se decide por Lola, esta se siente valorada, aunque se plantea una situación tan paradójica como triste, pues la protagonista se muestra confortada no por sí misma, sino por una mirada externa, que es la de un hombre.

Renia López-Ozieslo presenta una aportación de gran interés que versa sobre los comportamientos no verbales de los personajes de Almudena Grandes, basándose en el hecho de que la autora escribe siempre "a base de imágenes" (p. 145), lo que la lleva a concluir que es "importante analizar su obra [de Almudena Grandes] bajo esta perspectiva visual" (p. 171); metodología que abre importantes vías de análisis para futuros acercamientos a la obra de la escritora madrileńa.

El estudio de Christina Mougoyanni Hennessy se centra en $E l$ lector de Julio Verne. En esta novela, una vez más, es la recuperación de la memoria el tema articulador, que aquí se desarrolla poniendo el foco de atención en los ojos de un niño de nueve años, lo que es considerado por la autora del artículo como "la parte de la verdad que nos conviene" (p. 192).

También el libro para niños ¡Adiós Martínez! aparece analizado en este volumen misceláneo. Juan Senís Fernández, tras reflexionar sobre qué es escribir para niños, señala las características formales de un libro que cuenta la historia de 
un nińo y una niña que no encajan en los cánones tradicionales, pues presenta una innovadora relación de amistad entre los protagonista.

El penúltimo capítulo, firmado por Fátima Serra, se centra en El Corazón helado. Recuerda Serra que con esta novela, por primera vez Almudena Grandes se sumerge en la narrativa histórica de sucesos olvidados de perdedores y exiliados (p. 220) que fueron tácitamente prohibidos por el denominado Pacto de Silencio establecido durante la Transición. A través de la historia de tres generaciones de un par de familias, una fascista y otra republicana, el lector va aprehendiendo el pasado reciente de España, antes, durante y después de la Guerra Civil. El amor entre Raquel (nieta del republicano Ignacio Fernández Muñoz) y Álvaro, hijo del fascista Julio Carrión, anulan en esta muestra de la narrativa de Grandes la "liquidación de cuentas con el pasado” (p. 229).

El último capítulo se dedica a la muy reciente novela Los besos en el pan. Helena Talaya Manso aclara cómo los habitantes de un barrio de Madrid se enfrentan a la crisis económica. Para los jóvenes, acostumbrados a tenerlo todo, supone una catástrofe total, mientras que para los abuelos, que vivieron los años de miseria después de la Guerra Civil, se trata de un mero contratiempo. A este respecto recuerda la especialista cómo Almudena Grandes ha declarado en múltiples ocasiones su admiración por la resistencia, de modo que los habitantes aprenden a sufrir a lo largo de la crisis. El final abierto de la novela responde al hecho de que el libro fue escrito durante una crisis que todavía no ha terminado.

Se puede concluir, en síntesis, que Almudena Grandes. Memoria, compromiso y resistencia es un libro capital para los estudiosos de la obra de la escritora madrileńa, pues recopila un extenso material que es desde ya imprescindible para la mejor comprensión de sus obras. Además, la multitud de enfoques críticos, así como el análisis transversal de la narrativa de Grandes, hacen de este volumen una aportación que se debe saludar con entusiasmo, por lo que supone de utilidad tanto para los lectores que se inicien en el estudio de su obra como también para quienes deseen profundizar y conocer las últimas novedades bibliográficas y perspectivas metodológicas dentro de este ámbito de estudio.

Maria Gil de Sousa Universidad de Oporto 